\title{
Positive effect of tadalafil, a phosphodiesterase-5 inhibitor, on fracture healing in rat femur
}

\author{
Bir fosfodiesteraz 5 inhibitörü olan tadalafilin sıçan femurunda kırık iyileşmesi \\ üzerindeki olumlu etkisi
}

\author{
Güray Toğral, MD., Ş. Murat Arıkan, MD., ${ }^{1}$ Petek Korkusuz, MD., PhD² \\ Ramin Hashemi Hesar, DVM, ${ }^{2}$ M. Fatih Ekşioğlu, MD. ${ }^{1}$ \\ 1Department of Orthopedics and Traumatology, Dr. Abdurrahman Yurtaslan Ankara Oncology \\ Training and Research Hospital, Ankara, Turkey \\ ${ }^{2}$ Department of Histology \& Embryology, Hacettepe University, Faculty of Medicine, Ankara, Turkey
}

\begin{abstract}
Objectives: This study aims to investigate whether tadalafil accelerates fracture healing with an efficiency equal to that of sildenafil.

Materials and methods: Fracture healing was studied using a rat closed femur fracture model. Forty-eight male Wistar albino rats (mean age 13 weeks; range 12 to 14 weeks) were divided into three groups: 16 received sildenafil $(5 \mathrm{mg} / \mathrm{kg} /$ day per oral), 16 received tadalafil ( $1 \mathrm{mg} / \mathrm{kg} /$ day per oral), and 16 (control group) received saline daily. After two and five weeks, eight rats from each group were euthanized and bone healing was evaluated using radiographic, histologic, and histomorphometric analyses.
\end{abstract}

Results: At second week, radiologic score of tadalafil group was higher than the sildenafil treated groups and the sildenafil and tadalafil groups both had higher radiographic scores than the control group, all groups had similar scores at fifth week. The sildenafil and tadalafil treated group exhibited smaller callus diameter at the second week comparing to control group but the difference was not statistically significant, while callus diameter was significantly smaller in tadalafil group when compared to the control group in fifth week. Compared with the control group, cartilage percentage of the callus was lower in the sildenafil group at two weeks and lower in both the tadalafil and sildenafil groups at five weeks. There were no differences between the tadalafil and sildenafil groups regarding the radiographic scores, callus size, cartilage and osseous callus percentage, and the qualitative bridging scores at second or fifth week.

Conclusion: This study demonstrated that tadalafil accelerates fracture healing by enhancing osseous tissue formation similar to sildenafil.

Keywords: Angiogenesis; fracture; phosphodiesterase-5 inhibitors; sildenafil; tadalafil.
ÖZ

Amaç: $\mathrm{Bu}$ çalışmada tadalafilin kırık iyileşmesini sildenafille eşit bir etkinlikte hızlandırıp hızlandırmadığı araştırıld.

Gereç ve yöntemler: Kırık iyileşmesi sıçan kapalı femur kırığ $\breve{1}_{1}$ örneği kullanılarak incelendi. Kırk sekiz erkek Wistar albino sıçan (ort. yaş 13 hafta; dağılım 12-14 hafta) üç gruba ayrıldı: 16'sına sildenafil (5 mg/kg/gün, oral), 16'sına tadalafil ( $1 \mathrm{mg} / \mathrm{kg} / \mathrm{gün}$, oral) ve 16'sına (kontrol grubu) her gün serum fizyolojik verildi. İki ve beş hafta sonra her gruptan sekiz sıçana ötanazi yapıldı ve kemik iyileşmesi radyolojik, histolojik ve histomorfometrik analizlerle değerlendirildi.

Bulgular: İkinci haftanın sonunda tadalafil grubunun radyolojik skoru sildenafil grubundan yüksek ve her tadanafil hem sidenafil gruplarının skoru kontrol grubundan yüksekken, beşinci haftanın sonunda tüm grupların skorları benzerdi. Sildenafil ve tadalafil uygulanan gruplarda ikinci haftada kallus çapı kontrol grubuna göre daha küçük olarak saptanmış olsa da bu fark istatistiksel olarak anlamlı değildir. Beşinci haftadaki kallus çapı tadalafil grubunda kontrol grubuna göre anlamlı olarak küçüldü. Kontrol grubu ile karşılaştırıldığında, kallusun kıkırdak yüzdesi ikinci haftanın sonunda sildenafil grubunda daha düşük, beşinci haftanın sonunda hem tadalafil hem sildenafil grubunda daha düşüktü. Tadalafil ve sildenafil grupları arasında radyolojik skorlar, kallus çapı, kallusun kıkırdak ve kemik yüzdeleri ve köprüleşme skorları açısından ikinci ve beşinci haftanın sonunda farklılık yoktu.

Sonuç: Bu çalışma; tadalafilin sildenafil ile benzer şekilde kemik doku oluşumunu artırarak kırık iyileşmesini hızlandırdığını göstermiştir.

Anahtar sözcükler: Anjiogenez; kırık; fosfodiesteraz-5 inhibitörleri; sildenafil; tadalafil.

- Received: March 24, 2015 Accepted: September 15, 2015

- Correspondence: Güray Toğral, MD. Dr. Abdurrahman Yurtaslan Ankara Onkoloji Eğitim ve Araştırma Hastanesi Ortopedi ve Travmatoloji Anabilim Dalı, 06105 Yenimahalle, Ankara, Turkey. Tel: +90 312 - 3360909 Fax: +90 312 - 3340352 e-mail: dr_guray@hotmail.com 
Bone healing is a unique regenerative process comprising inflammation, mesenchymal cell condensation, chondrogenesis, angiogenesis, and

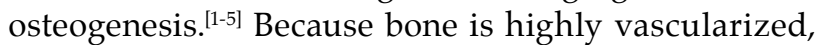
angiogenesis plays an extremely important role in bone formation during both bone development and fracture healing. ${ }^{[6,7]}$ Previous studies have demonstrated that the angiogenic and osteogenic factors associated with the proteins of vascular endothelial growth factor (VEGF) and cysteine-rich 61 (CYR61) are involved in the process of fracture healing, ${ }^{[6-9]}$ and that reduced vascularity at the fracture site is one of the most significant risk factors for delayed fracture healing. ${ }^{[3]}$

Sildenafil and tadalafil are inhibitors of the enzyme phosphodiesterase-5 (PDE5). Phosphodiesterase enzymes are widely distributed throughout the body and have numerous effects and functions. Phosphodiesterase- 5 inhibitors are beneficial in the treatment of erectile dysfunction, lower urinary tract symptoms caused by benign prostatic hyperplasia, chronic heart failure, pulmonary hypertension, essential hypertension, and ischemia. ${ }^{[10]}$ Recently, sildenafil has been reported to accelerate fracture healing and bone defect recovery. ${ }^{[11,12]}$ The beneficial effect of PDE5 inhibitors on bone healing is thought to be related to their effect on increasing nitric oxide synthase enzymes and CYR61 in healing fracture tissue. ${ }^{[12,13]}$

Tadalafil offers a longer plasma half-life and better bioavailability compared with sildenafil ${ }^{[14]}$ thus it may be more practical for daily usage. In this study, we aimed to investigate whether tadalafil accelerates fracture healing with an efficiency equal to that of sildenafil.

\section{MATERIALS AND METHODS}

This experimental study was conducted in the experimental research and histology laboratories between November 2013 and May 2014 following approval by the Ethics Committee of Ankara Training and Research Hospital (No. 17.12.2013/1). The procedures followed were in accordance with animal rights (Guide for the care and use of laboratory animals. www.nap.edu/catalog/5140. html). Forty-eight male Wistar albino rats (mean age 13 weeks; range 12 to 14 weeks) with a mean body weight of $340 \mathrm{~g}$ (range 295 to $352 \mathrm{~g}$ ) were randomly divided into the following three groups: 16 received $0.5 \mathrm{~mL}$ physiologic saline (control group), 16 received $5 \mathrm{mg} / \mathrm{kg}$ sildenafil (Viagra, $1 \mathrm{mg} / \mathrm{d}$; Pfizer, NY, IN, USA) (equivalent to $50 \mathrm{mg}$ adult human dose), and 16 received $1 \mathrm{mg} / \mathrm{kg}$ tadalafil (Cialis; Eli Lilly, Indianapolis, USA) (equivalent to $10 \mathrm{mg}$ adult human dose). Sildenafil and tadalafil were dissolved in saline and administered orally by gavage using a stomach tube. Treatment was started on the day of surgery and repeated at the same time daily until the day that the rats were euthanized. After two and five weeks, eight rats from each group were euthanized and bone healing was assessed.

After an adaptation period of five days, the rats fasted for three hours before surgery. Rats were placed in supine position after general anesthesia (ketamine, $50 \mathrm{mg} / \mathrm{kg}$, intraperitoneally). Under sterile conditions, a $5 \mathrm{~mm}$ medial parapatellar incision was made at the left knee to dislocate the patella laterally. After drilling a $0.5 \mathrm{~mm}$ diameter hole into the intracondylar notch, a $0.4 \mathrm{~mm}$ diameter injection needle was drilled into the intramedullary canal. Subsequently, a $1.0 \mathrm{~mm}$ diameter Kirschner wire was threaded into the intramedullary canal and in order to constitute standard closed fracture after surgery, the guillotine method defined by Bonnares and Einhorn ${ }^{[15]}$ was used. Producing a closed fracture in our experimental study provided the advantage of no loss of fracture hematoma from the fracture site. The same surgeon performed all the surgeries. Fracture and wire implant positions were confirmed on radiography (Figure 1a, d and g). The animals were permitted full-weight bearing and unrestricted movement after surgery. No antibiotics were administered pre- or postoperatively.

Plain radiography is commonly used for monitoring fracture healing. On the first day after surgery, ventrodorsal radiographs of all rats were obtained. At two weeks, 24 rats (eight from each group) were re-anesthetized and ventrodorsal radiographs of the healed femur were obtained. The same procedure was performed at five weeks using the remaining rats. Fracture healing was analyzed according to the classification recommended by Goldberg et al. ${ }^{[16]}$ stage 0 , radiographic nonunion; stage 1 , possible union; and stage 2, radiographic union.

After two and five weeks, 24 rats (eight from each group) were euthanized by an excessive dose of pentobarbital sodium (100 mg/ $\mathrm{kg}$, intraperitoneally). The left femur were resected and freed from the soft tissue, and placed in 10\% phosphate-buffered formalin $(\mathrm{pH}, 7.0)$ at room temperature for fixation. Samples were decalcified by immersion in De Castro solution, rinsed in buffer, and dehydrated in a graded ethanol series before embedding in paraffin. Five-micrometer-thick longitudinal serial sections were cut by using a rotary microtome (Microm, Germany). Sections were stained with hematoxylin and eosin and Masson's trichrome, and were evaluated for fracture healing and new bone formation by using a Leica DMR microscope 
(Leica, Microsystems CMS GmbH, Mannheim, Germany). Quantitative analysis of serial sections of the fracture area was carried out by using the Leica QWin Plus and Leica Application Suite (LAS) computer image analysis system according to suggestions provided by Gerstenfeld et al. ${ }^{[17]}$ Total callus area consisting of bone (osseous tissue), cartilage, and fibrous callus was noted. Ratios of osseous callus area to total callus area and of cartilaginous callus area to total callus area were calculated. The ratio of callus diameter to femoral bone diameter (cortical width plus marrow diameter) was also measured. Additionally, semiquantitative scoring was used to assess the quality of fracture bridging. ${ }^{[1]]}$

\section{Statistical analysis}

The statistical data were analyzed using Statistical Package for the Social Sciences (SPSS, Chicago, IL, USA) version 13.0 for Windows. All values were expressed as mean \pm standard deviation. The normality of the distribution and the homogeneity of the variances of the sample were established by using the Shapiro-Wilk test. Fracture healing parameters were analyzed by using nonparametric tests (the Kruskal-Wallis test for multiple comparisons and the Mann-Whitney $U$ test with Bonferroni correction as a post hoc test). Spearman test was used in order to analyze correlation between radiology and histology. Descriptive statistical values were expressed as median, minimum, and maximum. Differences were considered significant when $p$ was $<0.05$.

\section{RESULTS}

At two weeks, radiologic score of tadalafil group was higher than the sildenafil treated group, while the sildenafil and tadalafil groups both had higher radiographic scores than the control group $(\mathrm{p}<0.05)$ (Figure 1b, e, and h). There was no statistically significant difference between radiologic scores of groups fifth week ( $>0.05)$ (Figure 1c, f, and i). Radiographic and histomorphometric data did not show significant correlation in two and five weeks unless the cartilage volume and the total radiologic score of saline group at second week $(r=0.866$, $\mathrm{p}=0.005)$.

The sildenafil and tadalafil treated groups exhibited smaller callus diameter at the second week comparing to control (saline) group but the difference was not statistically significant ( $>>0.05)$ (Figure 2). Callus diameter was significantly smaller in tadalafil treated group when compared to that of the control group in five weeks $(\mathrm{p}=0.009)$ (Figure 3$)$.
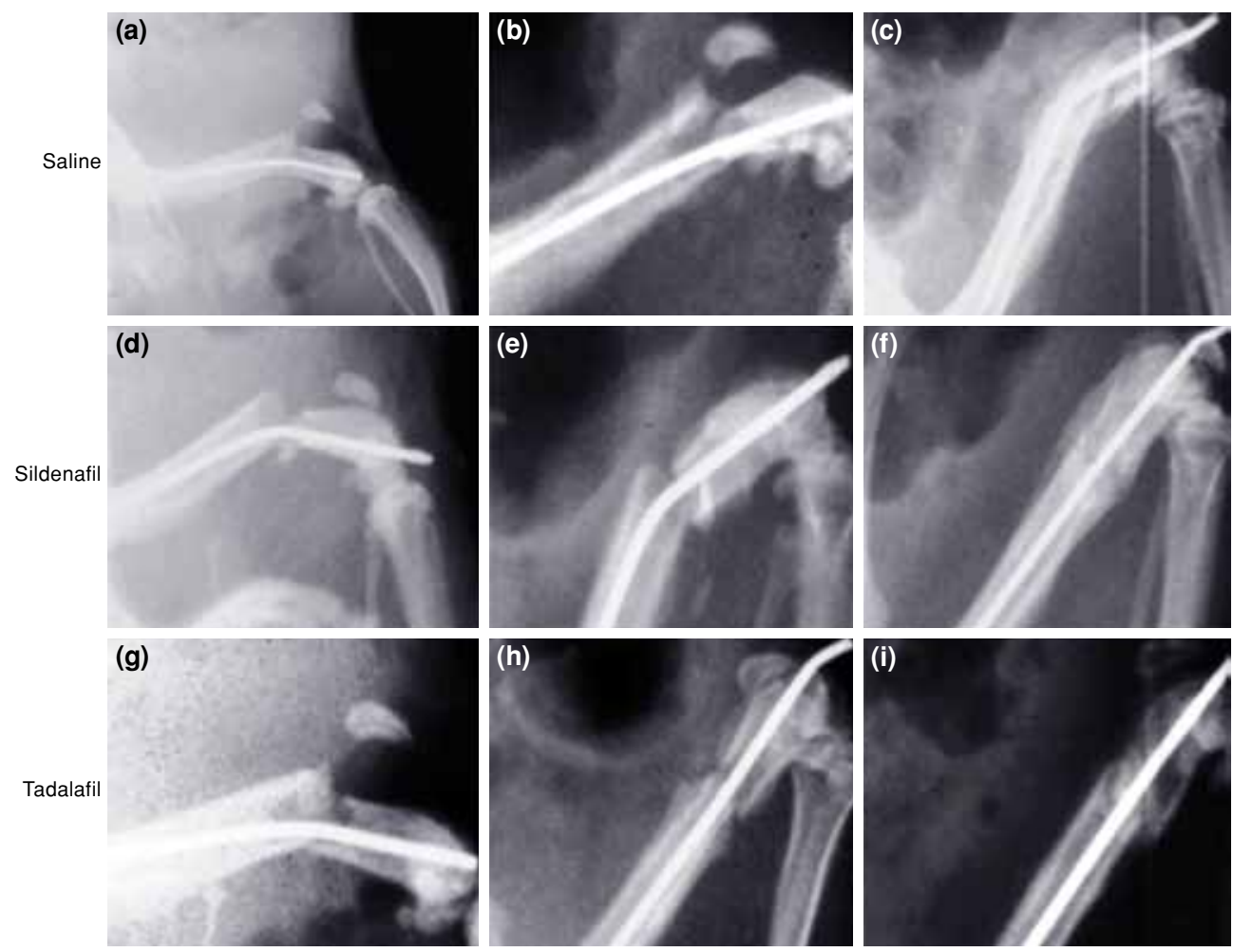

Figure 1. Plain radiographs of broken femur. Vertical lines respectively show sequences at beginning and end of second and fifth week. Horizontally, control group appears at first line; sildenafil group is at second line and tadalafil group can be seen at third line. 



Figure 2. Descriptive statistics of histomorphometric analysis for osseous tissue (bone) callus area/total callus area (TOTAr/Car \%), cartilaginous callus area/total callus area ( $\mathrm{CgAr} / \mathrm{Car} \%)$, callus diameter/femoral bone diameter (CDm/BDm) and bridging score are shown for sildenafil, tadalafil, and saline groups at second week. ${ }^{*} p<0.05$.

Cartilaginous callus percentage decreased, osseous callus percentage increased, and the bridging score increased from second to fifth week in all groups $(\mathrm{p}<0.05)$ (Figure 2-5). When compared with the control group, cartilaginous tissue percentage was lower in the sildenafil group at second week (Figure 4), and lower in both the tadalafil and sildenafil groups at fifth week (Figure 5). Thus sildenafil and tadalafil
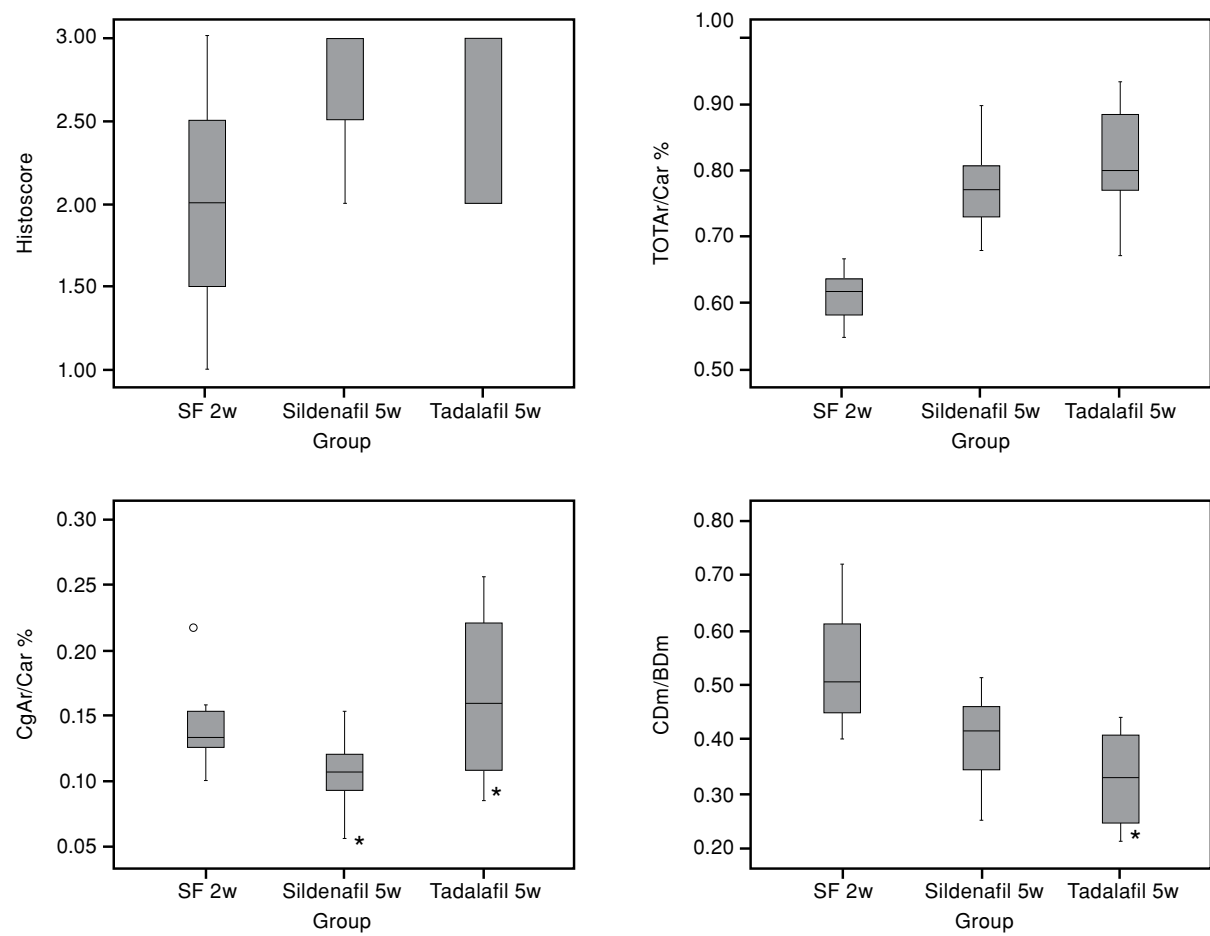

Figure 3. Descriptive statistics of histomorphometric analysis for osseous tissue (bone) callus area/total callus area (TOTAr/Car \%), cartilaginous callus area/total callus area (CgAr/Car \%), callus diameter/femoral bone diameter (CDm/BDm) and bridging score are shown for sildenafil, tadalafil, and saline groups at fifth week. ${ }^{*} p<0.05$. 

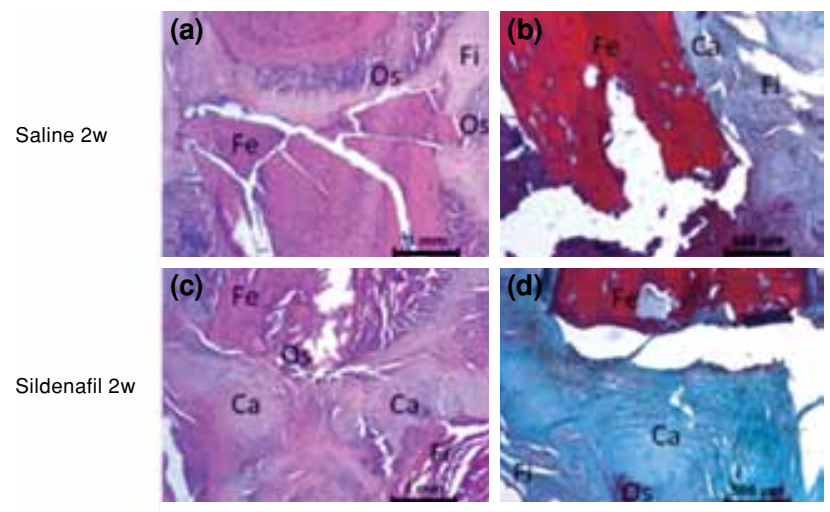

Tadalafil $2 w$
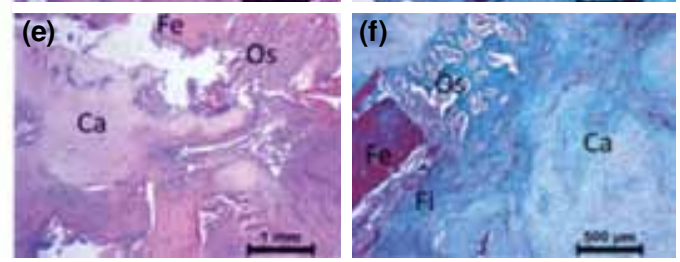

Figure 4. Left column shows hematoxylin \& eosin stained micrographs of the fracture gap at low power magnification (25x); right column shows Masson's trichrome stained micrographs at higher magnification (50x) at second week. Note that fracture healing occurs via both intramembranous and endochondral ossification in all groups. Cartilage models are dominating callus area in C-F. Fe: Fracture end; Ca: Cartilage; Fi: Fibrous connective tissue; Os: Bone.

treatment significantly accelerated osseous tissue formation in 2 and 5 weeks comparing to control ( $\mathrm{p}=0.027, \mathrm{p}=0.001$ and, $\mathrm{p}=0.001$ respectively). There was no statistically significant difference between sildenafil and tadalafil groups regarding the callus size, cartilage and osseous callus percentage, and the qualitative bridging scores at 2 and 5 weeks. ( $p>0.05)$.

\section{DISCUSSION}

In the present study, we tested the hypothesis that tadalafil accelerates fracture healing as well as sildenafil in a murine model. The data from our experiment confirmed this hypothesis. We demonstrated that both tadalafil and sildenafil enhanced bone healing by accelerating osseous fracture bridging. The reduced callus area with a decreased amount of cartilaginous tissue, compared with the control group, further supports that both tadalafil and sildenafil can accelerate the fracture healing process.

Fracture healing is a complex immune process as a component of the response to injury, which is influenced by a variety of local and systemic factors, such as type of bond, extent of injury to the bone and surrounding tissue, fixation, contribution of vascular tissue, age, nutrition, and presence of systemic disease. ${ }^{[18,19]}$ Angiogenic processes play a crucial role in the very early stages of fracture healing, affecting
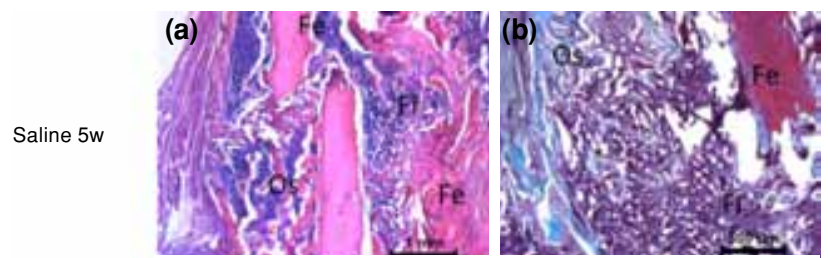

Sildenafil $5 w$
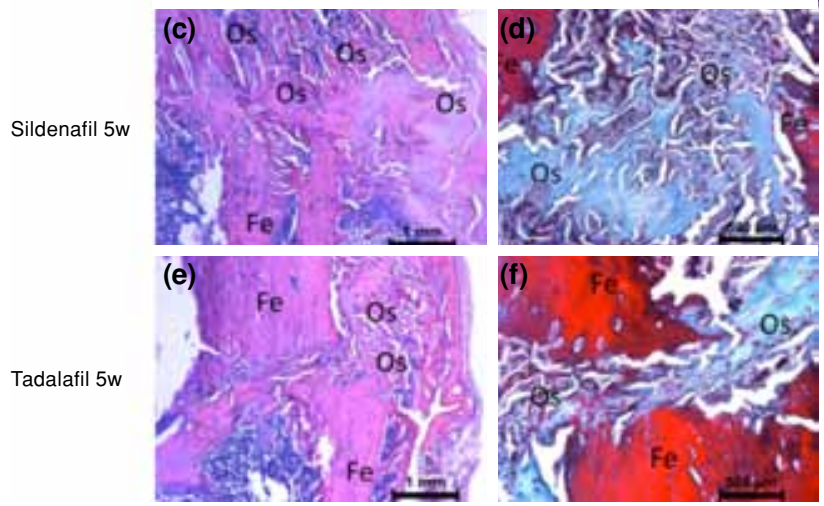

Figure 5. Left column shows hematoxylin \& eosin stained micrographs of fracture gap at low power magnification (25x); right column shows Masson's trichrome stained micrographs at higher magnification (50x) at fifth week. Note that osseous callus is dominating fracture gap and cartilage islands are disappearing compared to second week. Bone healing is accelerated in $\mathrm{C}-\mathrm{F}$ compared to $\mathrm{A}$ and $\mathrm{B}$. Fe: Fracture end; $\mathrm{Ca}$ : Cartilage; Fi: Fibrous connective tissue; Os: Bone.

both endochondral and intramembranous pathways of osteogenesis. ${ }^{[20-22]}$ Hausman et al. ${ }^{[23]}$ reported that antiangiogenic agents severely impair fracture healing by causing defective granulation tissue, absence of cartilage differentiation, and endochondral ossification. VEGF activity is essential for normal angiogenesis as well as appropriate callus architecture and mineralization in response to bone injury. It was demonstrated that sildenafil induced VEGF expression in human coronary arteriolar endothelial cells as an angiogenic response; ${ }^{[23]}$ however, the same effect was not observed in fracture healing by Histing et al. ${ }^{[1]}$ Their results might have been due to the time when analysis was performed. Local levels of endogenous VEGF peak at five days and decrease toward normal levels at day 10 after fracture ${ }^{[24]}$ or bony injury. ${ }^{[25]}$ However, analysis of Histing et al. ${ }^{[11]}$ occurred on day 14 after fracture.

Phosphodiesterases-5 are a family of enzymes that selectively catalyze the hydrolysis of $3^{\prime}$ - or 3',5'-cyclic phosphate bonds in adenosine and/or guanosine (cyclic adenosine monophosphate and/ or cyclic guanosine monophosphate [cGMP]). They regulate the cellular levels as well as the localization and duration of action of these cyclic nucleotide second messengers by controlling their degradation. There are 11 different subtypes of the PDE family 
(PDE1 to PDE11), each owning a specific tissue distribution. These enzymes are involved in many signal transduction pathways, and one of their functions is vascular smooth muscle proliferation and contraction. ${ }^{[26]}$ One isoform of PDE5 is PDE5A3, which is specific to smooth muscle. Nitric oxide (NO) is a highly reactive free radical that plays a critical role in vascular homeostasis: it regulates vascular tone by increasing cGMP levels and stimulating cGMP-dependent protein kinases. Intracellular levels of cGMP can be increased by $\mathrm{NO}$ or by inhibiting the breakdown through PDEs. ${ }^{[27]}$ The release of NO induces dilation of the blood via accumulation of cGMP. Sildenafil and tadalafil are inhibitors of PDE5 and decrease the breakdown of cGMP, leading to enhancement of the vasodilatory effect of NO. ${ }^{[26]}$ Nitric oxide is involved in inflammation, arthritis, and fracture repair ${ }^{[28]}$ During the bone healing process, endothelial cells, smooth muscle cells, neutrophils, recruited macrophage/histiocyte-type cells, and chondrocytes in the surrounding tissue become a source for NO. ${ }^{[28]}$ Studies have shown that PDE5 is located in vascular pulmonary and visceral smooth muscle as well as skeletal muscle. ${ }^{[29]}$ Thus, it has been hypothesized that PDE5 inhibitors can increase blood flow via a NO pathway in fractured bone. However, although they confirmed acceleration of fracture healing by sildenafil, Histing et al. ${ }^{[11]}$ also found that endothelial nitric oxide synthase (eNOS) levels were decreased to $50 \%$ at day 14 after fracture. Corbett et al. ${ }^{[28]}$ defined that two types of NOS are accompanied in fracture repair, in an inverse manner. Expression of eNOS is increased in cortical blood vessels and osteocytes, while localized principally in endosteal osteoblasts, and is seen in chondroblasts. In the early phase of fracture repair (day one after fracture), significantly elevated eNOS activity is observed with accompanying low activity of inducible nitric oxide synthase (iNOS). In the second week of fracture repair, the balance is reversed in favor of iNOS. ${ }^{[28]}$ The decreased eNOS levels in Histing et al.'s ${ }^{[11]}$ study may be based on the acceleration of fracture healing by sildenafil. Future studies analyzing both isotypes of NOS simultaneously may clarify the eNOS/iNOS dilemma associated with PDE5 inhibitor treatment of fractures.

On the other hand, sildenafil has been shown to affect expression of CYR61 -a growth factor inducible immediate early gene that has a role in cell proliferation and differentiation as well as extracellular matrix synthesis- in healing fractured tissue. ${ }^{[1]}$ CYR61 is upregulated in fracture callus, ${ }^{[0]}$ which stimulates endothelial cell migration and promotes osteoblast proliferation, differentiation, and cell adhesion. ${ }^{[30]}$ Lienau et al. ${ }^{[9]}$ concluded that reduced CYR61 expression in cartilage leads to less effective or suboptimal chondrocyte differentiation, resulting in longer persistence of cartilage in the callus and delayed healing. Also CYR61 has a role in promoting osteoblast proliferation and differentiation, ${ }^{[30,31]}$ and inhibits bone resorbing osteoclasts. ${ }^{[32]}$ Thus, the CYR61-promoting effect of sildenafil may accelerate cartilage resorption, promote osteoblast proliferation and differentiation, and inhibit osteoclast activity, all of which lead to fracture healing.

In the present study, fracture healing was studied after two and five weeks, as recommended by Histing et al. ${ }^{[1]}$ Making assessments at two different times helps to evaluate the bone healing process during the period of high activity within the callus, and to exclude the adverse effects of the PDE5 inhibitors, which may compromise definitive healing. In their study, Histing et al. ${ }^{[11]}$ showed that sildenafil accelerated fracture healing at two weeks, but, at the end of five weeks, the results were similar to those of the control group. In our study, the tadalafil and sildenafil groups had better histologic and histomorphometric scores compared with the control group at both two and five weeks. More studies should be conducted to elucidate whether these drugs only accelerate healing or whether they also promote better fracture healing.

This study compared the two currently licensed PDE5 inhibitors, which had similar results regarding bone healing acceleration. However, these PDE5 inhibitors also have some dissimilarities. Tadalafil has a longer half-life than sildenafil (17.5 hours versus 4 hours), which permits single daily dosing, and, unlike sildenafil, tadalafil absorption is unaffected by food or alcohol consumption. ${ }^{[14,33]}$ Tadalafil metabolism in the geriatric population and in patients with mild to moderate hepatic impairment is similar to that in the general population, ${ }^{[34,35]}$ whereas the metabolism of sildenafil is altered in these subgroups. ${ }^{[36]}$ Finally, the PDE5 selectivity of tadalafil is higher than that of sildenafil, which results in a better adverse effect profile. ${ }^{[37]}$

In conclusion we demonstrated that tadalafil accelerates fracture healing by enhancing osseous tissue formation similar to sildenafil. Considering its similar effect on bone healing, tadalafil may be more attractive for patients and clinicians.

\section{Acknowlement}

We thank Dr Eşref Oğuz Güven for assistance with methodology and for comments that greatly improved the manuscript. 


\section{Declaration of conflicting interests}

The authors declared no conflicts of interest with respect to the authorship and/or publication of this article.

\section{Funding}

The authors received no financial support for the research and/or authorship of this article.

\section{REFERENCES}

1. Akkaya S, Nazalı M, Kılıç A, Bir F. Cefazolin-sodium has no adverse effect on fracture healing in an experimental rabbit model. Eklem Hastalik Cerrahisi 2012;23:44-8.

2. Halıcı M, Öner M, Güney A, Canöz Ö, Narin F, Halıcı C. Melatonin promotes fracture healing in the rat model. Eklem Hastalik Cerrahisi 2010;21:172-7.

3. Keramaris NC, Calori GM, Nikolaou VS, Schemitsch EH, Giannoudis PV. Fracture vascularity and bone healing: a systematic review of the role of VEGF. Injury 2008;39:45-57.

4. Hankenson KD, Zimmerman G, Marcucio R. Biological perspectives of delayed fracture healing. Injury 2014;45:8-15.

5. Histing T, Garcia P, Matthys R, Leidinger M, Holstein $\mathrm{JH}$, Kristen A, et al. An internal locking plate to study intramembranous bone healing in a mouse femur fracture model. J Orthop Res 2010;28:397-402.

6. Oktaş B, Orhan Z, Erbil B, Değirmenci E, Ustündağ N. Effect of extracorporeal shock wave therapy on fracture healing in rat femural fractures with intact and excised periosteum. Eklem Hastalik Cerrahisi 2014;25:158-62.

7. Chaubey A, Grawe B, Meganck JA, Dyment N, Inzana J, Jiang $X$, et al. Structural and biomechanical responses of osseous healing: a novel murine nonunion model. J Orthop Traumatol 2013;14:247-57.

8. Lu CY, Chuang HY, Yu FJ, Sun LC, Shih YL, Chen FM, et al. Hypocaloric peripheral parenteral nutrition with lipid emulsion in postoperative gastrointestinal cancer patients. World J Gastrointest Oncol 2010;2:51-5.

9. Lienau J, Schell H, Epari DR, Schütze N, Jakob F, Duda GN, et al. CYR61 (CCN1) protein expression during fracture healing in an ovine tibial model and its relation to the mechanical fixation stability. J Orthop Res 2006;24:254-62.

10. Gur S, Kadowitz PJ, Serefoglu EC, Hellstrom WJ. PDE5 inhibitor treatment options for urologic and non-urologic indications: 2012 update. Curr Pharm Des 2012;18:5590-606.

11. Histing T, Marciniak K, Scheuer C, Garcia P, Holstein JH, Klein $\mathrm{M}$, et al. Sildenafil accelerates fracture healing in mice. J Orthop Res 2011;29:867-73.

12. Yaman F, Atilgan S, Günes N, Agacayak S, Günay A, Ucan MC, et al. Phosphodiesterase-5 inhibitors may facilitate bone defect recovery. Eur Rev Med Pharmacol Sci 2011;15:1301-5.

13. Akgül T, Alemdaroğlu B. Phosphodiesterase 5 inhibitors may facilitate bone fracture recovery. Med Hypotheses 2008;70:461-2.

14. Smith WB, McCaslin IR, Gokce A, Mandava SH, Trost L, Hellstrom WJ. PDE5 inhibitors: considerations for preference and long-term adherence. Int J Clin Pract 2013;67:768-80.
15. Bonnarens F, Einhorn TA. Production of a standard closed fracture in laboratory animal bone. J Orthop Res 1984;2:97-101.

16. Goldberg I, Peylan J, Yosipovitch Z. Late results of excision of the radial head for an isolated closed fracture. J Bone Joint Surg [Am] 1986;68:675-9.

17. Gerstenfeld LC, Wronski TJ, Hollinger JO, Einhorn TA. Application of histomorphometric methods to the study of bone repair. J Bone Miner Res 2005;20:1715-22.

18. Einhorn TA, Gerstenfeld LC. Fracture healing: mechanisms and interventions. Nat Rev Rheumatol 2015;11:45-54.

19. Wright PJ. Comparison of phosphodiesterase type 5 (PDE5) inhibitors. Int J Clin Pract 2006;60:967-75.

20. Kerimoğlu G, Yuluğ E, Kerimoğlu S, Çıtlak A. Effects of leptin on fracture healing in rat tibia. Eklem Hastalik Cerrahisi 2013;24:102-7.

21. Gerber HP, Vu TH, Ryan AM, Kowalski J, Werb Z, Ferrara N. VEGF couples hypertrophic cartilage remodeling, ossification and angiogenesis during endochondral bone formation. Nat Med 1999;5:623-8.

22. Hausman MR, Schaffler MB, Majeska RJ. Prevention of fracture healing in rats by an inhibitor of angiogenesis. Bone 2001;29:560-4.

23. Athanasopoulos AN, Schneider D, Keiper T, Alt V, Pendurthi UR, Liegibel UM, et al. Vascular endothelial growth factor (VEGF)-induced up-regulation of CCN1 in osteoblasts mediates proangiogenic activities in endothelial cells and promotes fracture healing. J Biol Chem 2007;282:26746-53.

24. Pufe T, Wildemann B, Petersen W, Mentlein R, Raschke M, Schmidmaier G. Quantitative measurement of the splice variants 120 and 164 of the angiogenic peptide vascular endothelial growth factor in the time flow of fracture healing: a study in the rat. Cell Tissue Res 2002;309:387-92.

25. Uchida S, Sakai A, Kudo H, Otomo H, Watanuki M, Tanaka $\mathrm{M}$, et al. Vascular endothelial growth factor is expressed along with its receptors during the healing process of bone and bone marrow after drill-hole injury in rats. Bone 2003;32:491-501.

26. Allanore Y. Phosphodiesterase 5 inhibitors in vascular systemic disorders. Joint Bone Spine 2012;79:338-40.

27. Kass DA, Takimoto E, Nagayama T, Champion HC. Phosphodiesterase regulation of nitric oxide signaling. Cardiovasc Res 2007;75:303-14.

28. Corbett SA, Hukkanen M, Batten J, McCarthy ID, Polak JM, Hughes SP. Nitric oxide in fracture repair. Differential localisation, expression and activity of nitric oxide synthases. J Bone Joint Surg [Br] 1999;81:531-7.

29. Carson CC, Lue TF. Phosphodiesterase type 5 inhibitors for erectile dysfunction. BJU Int 2005;96:257-80.

30. Si W, Kang Q, Luu HH, Park JK, Luo Q, Song WX, et al. CCN1/Cyr61 is regulated by the canonical Wnt signal and plays an important role in Wnt3A-induced osteoblast differentiation of mesenchymal stem cells. Mol Cell Biol 2006;26:2955-64.

31. Schütze N, Lechner A, Groll C, Siggelkow H, Hüfner M, Köhrle J, et al. The human analog of murine cystein rich protein 61 [correction of 16] is a 1alpha,25-dihydroxyvitamin D3 responsive immediate early gene in human fetal osteoblasts: regulation by cytokines, growth factors, and serum. Endocrinology 1998;139:1761-70. 
32. Crockett JC, Schütze N, Tosh D, Jatzke S, Duthie A, Jakob F, et al. The matricellular protein CYR61 inhibits osteoclastogenesis by a mechanism independent of alphavbeta3 and alphavbeta5. Endocrinology 2007;148:5761-8.

33. Bella AJ, Brock GB. Tadalafil in the treatment of erectile dysfunction. Curr Urol Rep 2003;4:472-8.

34. Uckert S, Stief CG, Jonas U. Current and future trends in the oral pharmacotherapy of male erectile dysfunction. Expert Opin Investig Drugs 2003;12:1521-33.
35. Forgue ST, Phillips DL, Bedding AW, Payne CD, Jewell $\mathrm{H}$, Patterson BE, et al. Effects of gender, age, diabetes mellitus and renal and hepatic impairment on tadalafil pharmacokinetics. Br J Clin Pharmacol 2007;63:24-35.

36. Carter AJ, Ballard SA, Naylor AM. Effect of the selective phosphodiesterase type 5 inhibitor sildenafil on erectile dysfunction in the anesthetized dog. J Urol 1998;160:242-6.

37. Corbin JD, Francis SH. Pharmacology of phosphodiesterase-5 inhibitors. Int $\mathrm{J}$ Clin Pract 2002;56:453-9. 